Gut, i972, 13, 293-296

\title{
The effect of octapressin on renal and intrarenal blood flow in cirrhosis of the liver ${ }^{1}$
}

\author{
M. C. KEW 2 , R. R. VARMA ${ }^{3}$, D. J. SAMPSON, AND SHEILA SHERLOCK \\ From the Departments of Medicine and Medical Physics, Royal Free Hospital, London
}

SUMMARY The effect of octapressin (2-phenylalanine-8-lysine vasopressin) on renal and intrarenal blood flow was studied in 11 normotensive cirrhotic patients with abnormal renal perfusion. Renal haemodynamic changes were assessed with the ${ }^{133}$ Xenon washout technique. Of the six patients given suppressor doses of octapressin intravenously renal blood flow improved in one only. A further three patients responded to the drug in a dose which increased the mean arterial pressure by 5 o. more $\mathrm{mm} \mathrm{Hg}$. The increase in mean renal blood flow was accompanied by an improvement in renal cortical perfusion. In two patients renal blood flow decreased after the administration of octapressin. These findings, in conjunction with previous reports, suggest that octapressin will only consistently improve renal perfusion in cirrhotic subjects who are hypotensive and in whom the mean arterial blood pressure is raised by the drug, but do not exclude the possibility that octapressin may have a direct renal circulatory effect in some patients.

Renal failure frequently develops in patients with advanced hepatic cirrhosis in the absence of an obvious cause (Hecker and Sherlock, 1956; Papper, Belsky, and Bleifer, 1959; Baldus, Feichter, and Summerskill, 1964a; Shear, Kleinerman, and Gabuzda, 1965). There is now a good deal of indirect evidence which suggests that the primary disturbance responsible for this grave complication is reduced renal perfusion (Baldus, Feichter, Summerskill, Hunt, and Wakim, 1964b; Schroeder, Shear, Sancetta, and Gabuzda, 1967; Tristani and Cohn, 1967; Epstein, Berk, Hollenberg, Adams, Chalmers, Abrams, and Merrill, 1970). It is therefore rational that treatment should be directed towards improving renal blood flow. Attempts to achieve this by the administration of plasma expanders have met with mixed success (Tristani and Cohn, 1967; McCloy, Baldus, Maher, and Summerskill, 1967; Reynolds, Lieberman, and Redeker, 1967) and more recently drugs which might be expected to reduce renal vascular resistance have been tried. Some have proved ineffective (Summerskill, 1966) while others, although improving renal perfusion, have not been suitable for clinical use (Barnardo, Baldus, and Maher, 1970; Vander, 1964). Octapressin (2-phenylalanine-8-lysine vasopressin; PLV-2), a synthetic analogue of vasopressin, has been reported in low doses to be a

${ }^{1}$ Financial support for the study was provided by the Ingram Trust. ${ }^{2}$ M.C.K. is in receipt of a Wellcome research grant.

${ }^{8}$ R.R.V. has a grant from the Medical College of Wisconsin.

Received for publication 8 February 1972. systemic vasoconstrictor and a renal vasodilator (Cohn, Tristani, and Khatri, 1968). As it also lowers portal pressure (Tsakiris, Haemmerli, and Bühlmann, 1964), octapressin should theoretically be an ideal agent to use in the treatment of functional renal failure in cirrhosis where renal perfusion is poor, portal hypertension frequently present, and the blood pressure often low (Hecker and Sherlock, 1956; Papper et al, 1959; Baldus et al, 1964a; Shear et al, 1965). Indeed Cohn, Tristani, and Khatri (1970) were able to raise the blood pressure and improve renal blood flow in three such patients. However, in 10 of the 11 cirrhotic subjects in whom renal perfusion has been improved by the administration of PLV-2 (Cohn et al, 1968, 1970), a simultaneous rise in blood pressure was produced and it may be argued that the increase in renal blood flow followed passively on the elevated arterial pressure. We have therefore investigated the effect of supressor doses of this drug on renal perfusion. The findings of Cohn et al (1968) suggested that, in addition to increasing renal blood flow, octapressin might improve renal cortical perfusion and hence glomerular filtration. We have used the ${ }^{133}$ Xenon washout technique so that the effect of the drug on the intrarenal distribution of blood flow could be assessed.

\section{Material and Methods}

The effect of octapressin on renal and intrarenal blood flow was measured in 11 patients with histo- 
logically proven cirrhosis of the liver. There were eight males and three females with a mean age of 49 years (range 37 to 62 years). Portal hypertension (as evidenced by the presence of oesophageal varices and splenomegaly) was present in eight subjects but none had ascites. The sodium intake of one patient (no. 8), who had previously had ascites, was restricted to less than 22 m-equiv per day: the remainder received a normal sodium intake. All patients had a systolic blood pressure of greater than $100 \mathrm{~mm}$ $\mathrm{Hg}$ at the time they were studied. Mean renal and outer cortical blood flow rates were reduced in all but one patient (no. 1) and seven had a subnormal distribution of blood flow to the outer renal cortex. Each patient had a normal blood urea concentration at the time they were investigated but in four instances creatinine clearance was reduced. No cause for abnormal renal haemodynamics other than an association with hepatic cirrhosis could be found.

Renal haemodynamic studies were performed at the time of coeliac axis or superior mesenteric arteriography to demonstrate the hepatic arterial and portal venous systems. The details of the procedure and its implications were explained to the patients and their consent was obtained. Renal and intrarenal blood flow was measured using the ${ }^{133}$ Xenon washout technique. The details of our method were given in a previous paper (Kew, Brunt, Varma, Hourigan, Williams, and Sherlock, 1971). A dose of $600-1000 \mu \mathrm{Ci}$ of ${ }^{133} \mathrm{Xenon}$ dissolved in $0.8-1.0 \mathrm{ml}$ of sterile isotonic saline solution was used. Background count rates were less than 30 counts per second while peak count rates after the injection were greater than 1500 counts per second. The washout curves were resolved into first (outer cortical blood flow) and second (juxtamedullary and outer medullary flow) components using an analog computer. Flow rates were corrected for the patient's haematocrit as described by Andersen and Ladefoged (1967). The percentage distribution of blood flow to these regions of the kidney was calculated from the zero time intercept of each component (Dobson and Warner, 1957). Mean renal blood flow was calculated from the slope of the initial curve (Ingvar and Lassen, 1961). Creatinine clearance was measured using the standard method and corrected for body surface area.

Three patients with a normal liver and kidneys were studied to determine the normal ranges for renal and intrarenal blood flow with this technique. The values for mean renal blood flow $(225 \pm 18$ $\mathrm{ml} / 100 \mathrm{~g} / \mathrm{min}$; mean $\pm \mathrm{SEM})$ and first component blood flow $\left(C_{1}\right)(317 \pm 11.8 \mathrm{ml} / 100 \mathrm{~g} / \mathrm{min})$ are lower than those found by Epstein et al (1970) using the same technique in 36 healthy individuals in whom renal arteriography was performed during assessment of their suitability as kidney donors (338 \pm $7 \mathrm{ml} / 100 \mathrm{~g} / \mathrm{min}$ and $410 \pm 9 \mathrm{ml} / 100 \mathrm{~g} / \mathrm{min}$ respectively). The percentage distribution of blood flow to $C_{1}$ (71 \pm 3.6) was similar to that found in the earlier study $(74 \pm 1)$. Based on the findings in our three subjects, we have taken the lower limits of normal for mean renal blood flow as $190 \mathrm{ml} / 100 \mathrm{~g} / \mathrm{min}, C_{1} 300 \mathrm{ml} /$ $100 \mathrm{~g} / \mathrm{min}$ and percentage distribution to $C_{1}$ as 60 .

After recording control washout curves, an intravenous infusion of octapressin was commenced and continued for at least 20 minutes before and throughout subsequent tracings. The doses of octapressin used ranged from 0.001 to 0.016 units $/ \mathrm{min}$. The patient's blood pressure was monitored before and during the infusion.

\section{Results}

The general characteristics, type of cirrhosis, selected tests of liver function, and serum creatinine and creatinine clearances of the 11 patients are summarized in Table I. The effect of octapressin on renal and intrarenal blood flow is shown in Table II. In six

\begin{tabular}{|c|c|c|c|c|c|c|c|c|c|c|c|c|}
\hline No. & Sex & Age & Cirrhosis & $\begin{array}{l}\text { Portal } \\
\text { Hyper- } \\
\text { tension }\end{array}$ & $\begin{array}{l}\text { Bilirubin } \\
(m g \%)\end{array}$ & $\begin{array}{l}\text { Albumin } \\
(g \%)\end{array}$ & $\begin{array}{l}\text { Thrombotest } \\
(\%)\end{array}$ & $\begin{array}{l}\text { Ast } \\
(u)\end{array}$ & $\begin{array}{l}\text { Alk Phos } \\
(\text { K.A.u) }\end{array}$ & $\begin{array}{l}\text { Serum } \\
\text { Creatinine } \\
(m g \%)\end{array}$ & $\begin{array}{l}\text { Creatinine } \\
\text { Clearance } \\
\left(\mathrm{ml} / \mathrm{min} / 1 \cdot 73 \mathrm{~m}^{2}\right)\end{array}$ & $\begin{array}{l}\text { Haemato- } \\
\text { crit }(\%)\end{array}$ \\
\hline
\end{tabular}

Table I The general characteristics, selected tests of liver function, and creatinine clearance in the 11 patients 


\begin{tabular}{|c|c|c|c|c|c|}
\hline \multirow[t]{2}{*}{ No. } & \multirow{2}{*}{$\begin{array}{l}\text { Dose (units) } \\
\text { min) }\end{array}$} & \multirow{2}{*}{$\begin{array}{l}\text { Mean } \\
\text { Arterial } \\
\text { Pressure } \\
(\mathrm{mm} \mathrm{Hg})\end{array}$} & \multirow{2}{*}{$\begin{array}{l}\text { Mean Renal } \\
\text { Blood Flow } \\
(\mathrm{ml} / 100 \mathrm{~g} / \\
\mathrm{min})\end{array}$} & \multicolumn{2}{|c|}{ Outer Cortical Blood Flow } \\
\hline & & & & $\begin{array}{l}\text { Rate } \\
(\mathrm{ml} / 100 \mathrm{~g} / \\
\mathrm{min})\end{array}$ & $\begin{array}{l}\text { Percentage } \\
\text { Distribution }\end{array}$ \\
\hline 1 & $\begin{array}{l}\mathrm{C}^{1} \\
0.001 \\
0.002\end{array}$ & $\begin{array}{l}84 \\
84 \\
84\end{array}$ & $\begin{array}{l}177,208 \\
172 \\
111\end{array}$ & $\begin{array}{l}292,324 \\
285 \\
191\end{array}$ & $\begin{array}{l}45,56 \\
62 \\
47\end{array}$ \\
\hline 2 & $\begin{array}{l}C \\
0.004 \\
0.008\end{array}$ & $\begin{array}{l}104 \\
106 \\
106\end{array}$ & $\begin{array}{l}142,111 \\
76 \\
52\end{array}$ & $\begin{array}{l}200,240 \\
200 \\
200\end{array}$ & $\begin{array}{l}63,40 \\
21 \\
13\end{array}$ \\
\hline 3 & $\begin{array}{l}C \\
0.004 \\
0.008\end{array}$ & $\begin{array}{l}96 \\
97 \\
98\end{array}$ & $\begin{array}{l}44 \\
37 \\
41\end{array}$ & $\begin{array}{l}44 \\
37 \\
41\end{array}$ & $\begin{array}{l}10 \\
10 \\
10\end{array}$ \\
\hline 4 & $\begin{array}{l}\mathrm{C} \\
0.008 \\
0.016\end{array}$ & $\begin{array}{l}74 \\
78 \\
78\end{array}$ & $\begin{array}{l}55,36 \\
37,54 \\
41\end{array}$ & $\begin{array}{l}177,36 \\
37,54 \\
41\end{array}$ & $\begin{array}{l}17,10 \\
10,10 \\
10\end{array}$ \\
\hline 5 & $\begin{array}{l}\mathrm{C} \\
0.004\end{array}$ & $\begin{array}{r}98 \\
101\end{array}$ & $\begin{array}{l}57 \\
88,83\end{array}$ & $\begin{array}{l}57 \\
137,128\end{array}$ & $\begin{array}{l}10 \\
43,53\end{array}$ \\
\hline 6 & $\begin{array}{l}C \\
0.001 \\
0.002\end{array}$ & $\begin{array}{l}105 \\
105 \\
109\end{array}$ & $\begin{array}{l}134,130 \\
82 \\
106\end{array}$ & $\begin{array}{l}233,233 \\
149 \\
172\end{array}$ & $\begin{array}{l}67,55 \\
30 \\
63\end{array}$ \\
\hline 7 & $\begin{array}{l}C \\
0.001 \\
0.002\end{array}$ & $\begin{array}{l}94 \\
99 \\
99\end{array}$ & $\begin{array}{l}135,116 \\
277,191 \\
166\end{array}$ & $\begin{array}{l}135,173 \\
388,306 \\
264\end{array}$ & $\begin{array}{l}10,57 \\
59,59 \\
52\end{array}$ \\
\hline 8 & $\begin{array}{l}\mathrm{C} \\
0.001 \\
0.002\end{array}$ & $\begin{array}{l}86 \\
88 \\
91\end{array}$ & $\begin{array}{l}153,122 \\
196 \\
95\end{array}$ & $\begin{array}{l}222,207 \\
318 \\
251\end{array}$ & $\begin{array}{l}70,57 \\
61 \\
26\end{array}$ \\
\hline 9 & $\begin{array}{l}C \\
0.004 \\
0.008\end{array}$ & $\begin{array}{r}96 \\
98 \\
101\end{array}$ & $\begin{array}{l}109,129 \\
155 \\
105\end{array}$ & $\begin{array}{l}287,218 \\
226 \\
231\end{array}$ & $\begin{array}{l}40,64 \\
72 \\
34\end{array}$ \\
\hline 10 & $\begin{array}{l}\mathrm{C} \\
0.001 \\
0.005\end{array}$ & $\begin{array}{l}103 \\
115 \\
119\end{array}$ & $\begin{array}{l}165,177 \\
260 \\
191\end{array}$ & $\begin{array}{l}265,277 \\
359 \\
359\end{array}$ & $\begin{array}{l}64,63 \\
67 \\
57\end{array}$ \\
\hline 11 & $\begin{array}{l}\mathrm{C} \\
0.001\end{array}$ & $\begin{array}{l}89 \\
97\end{array}$ & $\begin{array}{l}126 \\
116\end{array}$ & $\begin{array}{l}191 \\
188\end{array}$ & $\begin{array}{l}57 \\
57\end{array}$ \\
\hline
\end{tabular}

Table II The effect of octapressin on mean renal and outer cortical blood flow and mean arterial blood pressure

${ }^{2}$ Control

patients (nos. 1-6) the mean arterial blood pressure either did not change during the infusion of octapressin or increased by 4 or less $\mathrm{mm} \mathrm{Hg}$. In one (no. 5) renal perfusion improved with a dose of 0.004 units/min. No increase in renal blood flow occurred in the others with doses varying from 0.001 to 0.016 units/min. In the remaining five patients (nos. 7-11) the mean arterial pressure rose by 5 or more $\mathrm{mm} \mathrm{Hg}$ during the administration of the drug. In two (nos. seven and 8) mean renal and outer cortical flow rates increased with a dose of 0.001 units $/ \mathrm{min}$ and 1 (no. 10) with 0.001 and 0.005 units $/ \mathrm{min}$. Renal perfusion was not significantly changed in the others with doses ranging from 0.001 to 0.008 units $/ \mathrm{min}$.

In two of the patients (nos. 7 and 8) who responded initially to a dose of 0.001 units of octapressin per minute, renal perfusion returned towards the control values when the dose was doubled. A similar decrease occurred in one patient (no. 1) who started off with a normal renal and cortical blood flow when he received 0.002 units/min and in another patient (no. 2) who initially had abnormal renal perfusion (dose
0.004 units/min). There was no obvious correlation: between tests of liver function or the type of cirrhosis and the response to octapressin.

\section{SIDE EFFECTS}

The doses of octapressin used produced no objective effects. Specifically, none of the patients experienced abdominal cramps, headache, or chest pain. Facial pallor was evident in the patient in whom the mean arterial pressure increased by $16 \mathrm{~mm} \mathrm{Hg}$.

\section{Discussion}

The effects of vasopressin and its analogue octapressin on renal blood flow have been variable: synthetic vasopressin improved renal perfusion in anaesthetized cats (Barer, 1963) but had no effect in conscious dogs (Brooks and Pickford, 1958) or man (Maxwell and Breed, 1951), while octapressin increased renal blood flow in dogs with haemorrhagic or endotoxic shock (Longo, Morris, Smith, Beck, and Assali, 1964; Texter, Abella, Laureta, del Greco, and Chou, 1966) but not in normotensive dogs or human subjects (Longo et al, 1964). In the only study to date in cirrhotic subjects Cohn and his coworkers (1968) were able to reduce renal vascular resistance and improve renal perfusion using small doses of octapressin. Although this almost invariably accompanied a rise in systemic blood pressure, they did not think that it was a passive increase in renal blood flow secondary to the rise in arterial pressure because in one patient renal perfusion improved without any change in mean arterial pressure and in another a direct arterial infusion of the drug in very small doses led to a fall in renal vascular resistance. A direct effect of octapressin on the renal vessels would be confirmed if renal blood flow could be shown to increase in response to subpressor doses. Using doses which produced a rise in mean arterial blood pressure of 4 or less $\mathrm{mm} \mathrm{Hg}$, we were able to improve renal perfusion in only one of six cirrhotic subjects. Renal blood flow increased in three out of five patients in whom a rise in mean arterial pressure of 5 or more $\mathrm{mm} \mathrm{Hg}$ was produced.

The marked instability of renal perfusion in cirrhotic patients (Epstein et al, 1970; Kew et al, 1971) makes the interpretation of drug-induced changes difficult: it is entirely possible that the increase in renal perfusion in four of our patients might reflect a change in vasomotor tone unrelated to the drug, and the fact that in two other patients renal blood flow decreased after the administration of octapressin strengthens this possibility. For a drug-induced change to be regarded as significant in these circumstances, it would have to be consistent.

It may be argued that we failed to produce a con- 
sistent response to octapressin because too small a dose was used. Although our doses were usually smaller than those used in the earlier study of Cohn et al (1968) (0.004 to $0.02 \mathrm{units} / \mathrm{min})$ they were of the same order as those which subsequently produced good results in three patients with hepatorenal failure (Cohn et al, 1970). Moreover, the four patients who did respond all received small doses (0.001 units/min in three and 0.004 units/min in one). Furthermore, in two of our patients who responded to octapressin in a dose of 0.001 units/min renal blood flow seemed to decrease again when larger doses were used. A similar phenomenon was noted by Cohn and his coworkers (1968) with doses in excess of 0.02 units $/ \mathrm{min}$. There were undoubtedly differences in the type of patients investigated in the two studies. Eight of the 11 subjects studied by Cohn et al $(1968,1970)$ were hypotensive at the time, while all of our patients had a resting systolic blood pressure greater than $100 \mathrm{~mm} \mathrm{Hg}$. This suggests that octapressin will only consistently increase renal blood flow if a simultaneous rise in blood pressure is produced, a conclusion similar to that reached in experiments in dogs (Longo et al, 1964; Texter et al, 1966). The fact that this effect is not specific to the reduced renal perfusion which occurs in patients with cirrhosis of the liver is indicated by the good response in renal blood flow to octapressin in a patient shocked for another reason (Cohn et al, 1968). Other differences may also have contributed to the variable results. For example, all of the patients studied by Cohn's group had decompensated cirrhosis with ascites and seven had azotaemia and oliguria, while all of our patients had a normal blood urea concentration and none had ascites at the time they were investigated.

Cohn et al (1968) found that the improvement in renal blood flow with octapressin was associated with a rise in the extraction ratio of para-amino hippurate and an increase in the rate of transit of indocyanine green through the kidney, suggesting that cortical perfusion was improved by the drug. As the abnormal renal perfusion in cirrhotic subjects is thought to be responsible for a decrease in glomerular filtration rate and ultimately azotaemia and oliguria, restoration of cortical blood flow should result in an improvement in renal function. In the present series cortical perfusion improved in the four patients in whom mean renal blood flow increased with octapressin.

We are grateful to Miss C. A. Limbrick and our colleagues in the Department of Radiology for their assistance.
References

Andersen, A. M., and Ladefoged, J. (1967). Partition coefficient of ${ }^{138}$ xenon between various tissues and blood in vivo. Scand.J. Lab. clin. Invest., 19, 72-78.

Baldus, W. P., Feichter, R. N., and Summerskill, W. H. J. (1964a). The kidney in cirrhosis. I. Clinical and biochemical features of azotaemia in hepatic failure. Ann. intern. Med., 60, 353-365.

Baldus, W. P., Feichter, R. N., Summerskill, W. H. J., Hunt, J. C., and Wakim, K. G. (1964b). The kidney in cirrhosis. II. Disorders of renal function. Ann. intern. Med., 60, 366-377.

Barer, G. R. (1963). Action of vasopressin, a vasopressin analogue (PLV-2), oxytocin, angiotensin, bradykinin and theophylline ethylene diamine on renal blood flow in the anaesthetised cat. $J$. Physiol. (Lond.), 169, 62-72.

Barnardo, D. E., Baldus, W. P., and Maher, F. T. (1970). Effects of dopamine on renal function in patients with cirrhosis. Gastroenterology, 58, 524-531.

Brooks, F. P., Pickford, M. (1958). The effect of posterior pituitary hormones on the excretion of electrolytes, in dogs. J. Physiol. (Lond.), 142, 468-493.

Cohn, J. N., Tristani, F. E., and Khatri, I. M. (1968). Systemic vasoconstrictor and renal vasodilator effects of PLV-2 (Octapressin) in man. Circulation, 38, 151-157.

Cohn, J. N, Tristani, F. E., and Khatri, I. M. (1970). Renal vasodilator therapy in the hepatorenal syndrome. Med. Ann. D.C., 39, 1-7.

Dobson, E. L., and Warner, G. F. (1957). Measurement of regional sodium turnover rates and their application to the estimation of regional blood flow. Amer. J. Physiol., 189, 269-276.

Epstein, M., Berk, D. P., Hollenberg, N. K., Adams, D. F., Chalmers, T. C., Abrams, H. L., and Merrill, J. P. (1970). Renal failure in the patient with cirrhosis: the role of active vasoconstriction. Amer. J. Med., 49, 175-185.

Hecker, R., and Sherlock, S. (1956). Electrolyte and circulatory changes in terminal liver failure. Lancet, 2, 1121-1125.

Ingvar, D. H., and Lassen, N. A. (1961). Quantitative determination of regional cerebral blood flow in man. Lancet, 2, 806-807.

Kew, M. C., Brunt, P. W., Varma, R. R., Hourigan, K. J., Williams, H. S., and Sherlock, S. (1971). Renal and intrarenal blood flow in cirrhosis of the liver. Lancet, 2, 504-510.

Longo, L. D., Morris, J. A., Smith, R. W., Beck, T., and Assali, N. S. (1964). Hemodynamic and renal effects of octapressin. Proc. Soc. exp. Biol. (N.Y.), 115, 766-770.

McCloy, R. M., Baldus, W. P., Maher, F. T., and Summerskill, W. H. J. (1967). Effects of changing plasma volume, serum albumin concentration, and plasma osmolality on renal function in cirrhosis. Gastroenterology, 53, 229-239.

Maxwell, M. H., and Breed, E. S. (1951). The effect of the intravenous administration of pitressin on renal function in man. $J$. Pharmacol. exp. Ther., 103, 190-195.

Papper, S., Belsky, J. L., and Bleifer, K. H. (1959). Renal failure in Laennec's cirrhosis of the liver. I. Description of clinical and laboratory features. Ann. intern. Med., 51, 759-773.

Reynolds, T. B., Lieberman, F. L., and Redeker, A. G. (1967). Functional renal failure with cirrhosis: the effect of plasma expansion therapy. Medicine (Baltimore), 46, 191-196.

Schroeder, E. T., Shear, L., Sancetta, S. M., and Gabuzda, J. G. (1967). Renal failure in patients with cirrhosis of the liver. III. Evaluation of intrarenal blood flow by para-aminohippurate extraction and response to angiotensin. Amer. J. Med., 43 887-896.

Shear, L., Kleinerman, J., and Gabuzda, G. J. (1965). Renal failure in patients with cirrhosis of the liver. I. Clinical and pathologic characteristics. Amer. J. Med., 39, 184-198.

Summerskill, W. H. J. (1966). Hepatic failure and the kidney. Gastroenterology, 51, 94-107.

Texter, E. C., Jr., Abella, R., Laureta, H. C., del Greco, F., and Chou, C. C. (1966). Differential effects of vasopressin and phenylalanines-vasopressin on regional vascular resistance and renal function. Ann. intern. Med., 64, 1153.

Tristani, F. E., and Cohn, J. N., (1967). Systemic and renal hemodynamics in oliguric hepatic failure: effect of volume expansion. J. clin. Invest., 46, 1894-1906.

Tsakiris, A., Haemmerli, U. P., and Bühlmann, A. (1964). Reduction of portal venous pressure in cirrhotic patients with bleeding from oesophageal varices, by administration of a vasopressin derivative, phenylalanine $e^{3}-$ lysine $e^{3}$-vasopressin. Amer. J. Med., 36, 825-839.

Vander, A. J. (1964). Effects of acetylcholine, atropine, and physostigmine on renal function in the dog. Amer. J. Physiol., 206, 492-498. 